肝円索内に巨大な血腫を形成した胆囊印環細胞癌の 1 例

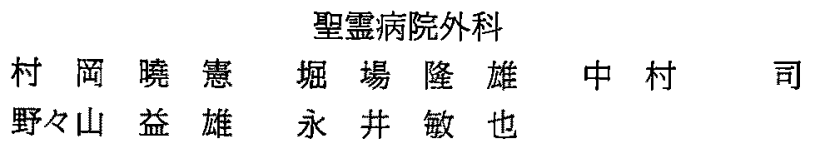

われわれは胆石胆鸾炎にて内科入院し，精查中に肝円索内に巨大な血腫を形成したた め, 緊急手術を施行した胆辜原発印環細胞癌を経験した。症例は72歳女性で, 急性腹症 にて当院救急外来に搬送. 胆石胆襄炎と診断され, 内科入院となった．保存的治療にて 一時軽快するも, 再び上腹部激痛を訴え, 再度 CT 施行したところ肝淢内より表面に 突出する腫瘤と中等量の腹水を認めた為，胆異穿孔が疑われ外科に紹介．同日緊急手術

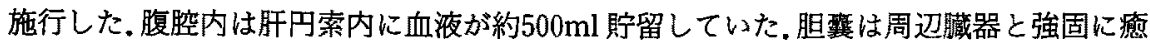

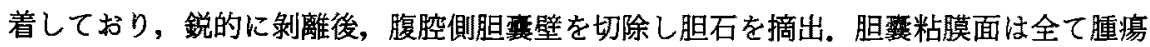

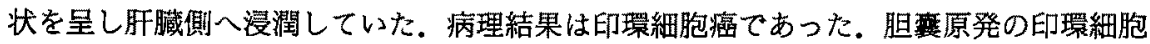
癌は報告例も少なく稀であり，また肝円索内血腫と合侀した報告例はないことから，若 干の文献的考察を加え報告する。

索引用語：胆石胆毫炎，印環細胞癌，肝円索血腫

緒言

胆赛原発の印環細胞癌は比較的稀な疾患である.今 回われわれは肝円索内に巨大な血腫を形成したため緊 急手術となった, 胆豪原発印環継胞癌の 1 例を経験し たので報告する。

症例

患者：72歳，女性.

主訴：上腹部痛.

既往歴：以前より糖尿病および高血圧を指摘されて いたが，特に治療を受けることなく放置していた。

現病歴：平成16年 9 月12日朝より右上腹部に疼痛を 認め, 昼頃急激に増強してきた為, 救急車にて当院救 急外来に搬送された。腹部 CT 検查, 腹部超音波検查 (以下US)にて胆石胆䨳炎と診断.内科入院となり抗 生物質等にて保存的に治療を開始。一旦疼痛も軽減し， 軽快に向かっていたが，9月18日に再び上腹部に激痛 出現. 19日に再度施行したCTにて肝内より肝表面に 乫出する液体の貯留あり. 白血球数, CRP 値ともに再 度上昇し，腹水も認めたため，外科依頼となった。

2004 年 5 月 10 日受付 2004 年 8 月 18 日採用 〈所属施設住所〉

干466-8633 名古屋市昭和区川名山町56
外科初診時現症：体温 $37.2^{\circ} \mathrm{C}$. 脈拍毎分 90 回. 眼瞼 結膜に筫血なし, 眼球結膜に黄疸なし.腹部は平坦で, 右 上腹部を中心に強い疼痛，圧痛あり。筋性防御も認めた。

血液検查所見：内科入院時においては，血液一般， 生化学検查にて白血球数と CRP 值の著明な上昇を認 め, 高血糖も認めた。CEA, CA19-90㯵煬マーカーは 共に正常值であった(表 1). 外科受診時では一旦正常 化した白血球数も再び上昇し，炎症の再燃を認めた。

腹部 CT 検查所見：内科入院時に施行された CT 検 查では, 胆石および胆㖶壁の肥厚, 肝左葉胆黄床辺り に膿湟と思われる低吸収域を認め大（図 1 )。外科紹介 時のCT 画像においては肝左葉内に新たに円形の巨大 な低吸収域があり，その内腔には niveau 形成を認め, 液体の貯留を示唆していた，肝蔵の外側にも中等度の 腹水の貯留を認めた（図 2 ).

上記より胆石胆謈炎および胆顀穿孔による腹膜炎が 疑われ，同日緊急手術を施行した。

手術所見：右肋弓下切開にて開腹. 腹羟内には暗赤 色を呈する血液が $500 \mathrm{ml}$ 程貯留していた. 吸引の後検 索すると, 血腫は肝円索内であり, 周囲臓器とは隔絶 され明らかな交通はなかった. 血腫を大きく開創し内 腔を㭘索したが，血腫内には明らかな出血点を確認出 来なかった。胆䧶は大網，横行結腸，胃と浸润の如き 
表 1 入院時血液検查所見

\begin{tabular}{|c|c|c|c|c|c|}
\hline WBC & 15,500 & $\mid \mu 1$ & $\mathrm{TP}$ & 7.7 & $\mathrm{~g} / \mathrm{dl}$ \\
\hline $\mathrm{RBC}$ & $426 \times 10^{4}$ & )$^{4} \quad / \mu I$ & Alb & 3.6 & $\mathrm{~g} / \mathrm{dl}$ \\
\hline $\mathrm{Hb}$ & 12.9 & $\mathrm{~g} / \mathrm{dl}$ & TTT & 3.6 & 単位 \\
\hline $\mathrm{Ht}$ & 38.2 & $\%$ & ZTT & 11.6 & 単位 \\
\hline \multirow[t]{2}{*}{ Plt } & \multicolumn{2}{|c|}{$43.1 \times 10^{4} / \mu 1$} & T.Bil & \multicolumn{2}{|c|}{$0.8 \mathrm{mg} / \mathrm{dl}$} \\
\hline & & & $\gamma$-GTP & 42 & $\mathrm{U} / \mathrm{L}$ \\
\hline \multirow[t]{2}{*}{ CRP } & \multirow[t]{2}{*}{24.94} & \multirow[t]{2}{*}{$\mathrm{mg} / \mathrm{dl}$} & AST & 13 & $\mathrm{U} / \mathrm{L}$ \\
\hline & & & ALT & 14 & $\mathrm{U} / \mathrm{L}$ \\
\hline CEA & 2.2 & $\mathrm{ng} / \mathrm{ml}$ & ALP & 251 & $\mathrm{U} / \mathrm{L}$ \\
\hline \multirow[t]{2}{*}{ CA19-9 } & \multirow[t]{2}{*}{25.9} & \multirow[t]{2}{*}{$\mathrm{U} / \mathrm{ml}$} & LDH & 182 & $U / L$ \\
\hline & & & $\mathrm{ChE}$ & 335 & $\mathrm{U} / \mathrm{L}$ \\
\hline \multirow[t]{2}{*}{ PT } & 77.0 & $\%$ & BUN & \multicolumn{2}{|c|}{$7.7 \mathrm{mg} / \mathrm{dl}$} \\
\hline & 14.8 & 秒 & $\mathrm{Cr}$ & \multicolumn{2}{|c|}{$0.5 \mathrm{mg} / \mathrm{dl}$} \\
\hline APTT & 29.3 & 秒 & $\mathrm{Na}$ & 132 & $\mathrm{mEq} / \mathrm{l}$ \\
\hline \multirow[t]{2}{*}{ c.APTT } & 33.6 & 秒 & $\mathrm{K}$ & \multicolumn{2}{|c|}{$4.1 \mathrm{mEq} / 1$} \\
\hline & & & $\mathrm{Cl}$ & \multicolumn{2}{|c|}{$98.2 \mathrm{mEq} / \mathrm{l}$} \\
\hline \multirow[t]{2}{*}{ HPT } & \multirow[t]{2}{*}{59} & \multirow[t]{2}{*}{$\%$} & BS & 310 & $\mathrm{mg} / \mathrm{dl}$ \\
\hline & & & HbAlc & 12.7 & $\%$ \\
\hline
\end{tabular}

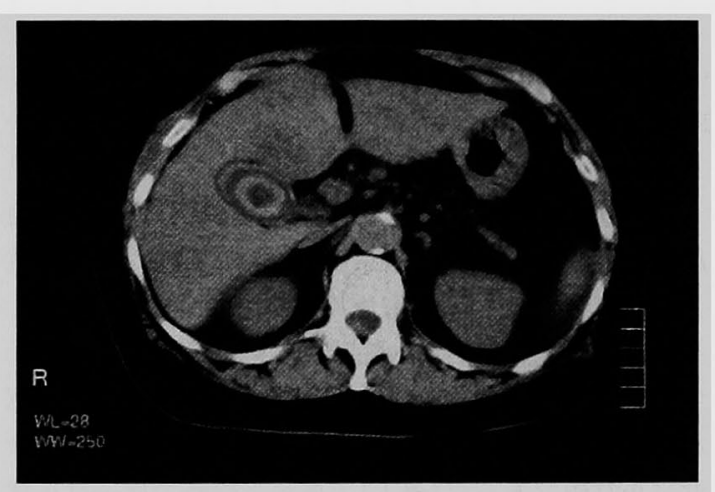

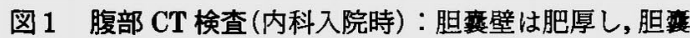
内には $3 \mathrm{~cm}$ 大の結石を認める. 胆䧶に接する肝左葉に 淡い低吸収域を認める。

瘑着を認め，鋭的に剝離すると底部を中心に腫瘍を認 めた．旰側の胆要床には乳白色の腫場が連続して存在 し，腫場と肝臓との間に裂傷があり，そこより出血を 認め血性腹水となっていた，以上より胆壤癌および肝 床への直接浸潤を強く疑った. 近傍腹膜には播種等は

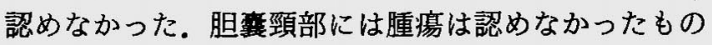
の強い炎症があり，まず可及的に腫場および腹腔側胆

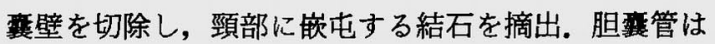

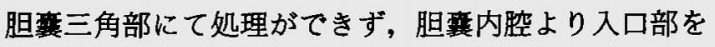
縫合閉鎖するに止めた. 止血を確認し，切離面にドレ ーンを留置して, 閉腹した。

切除標本 : 摘出した腹腔側胆囊壁の内腔には, 結石

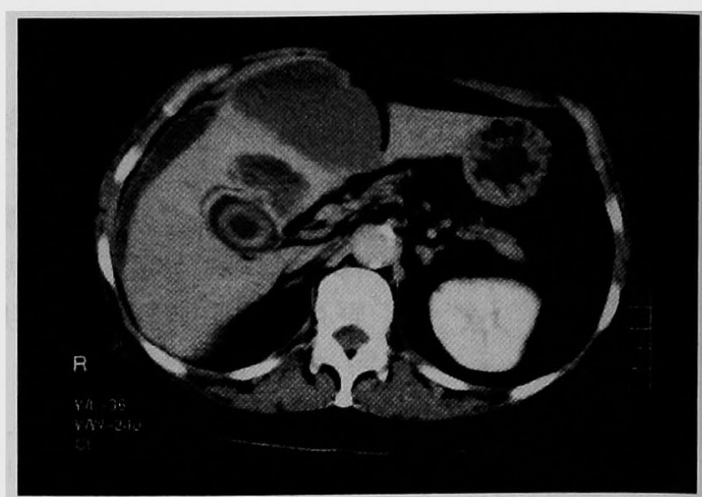

図2 腹部造影 CT 検査（外科受䛦時）：肝左葉臍部の辺 りに巨大な低吸収域を新たに認め, 肝外側に中等度の 腹水を認める。

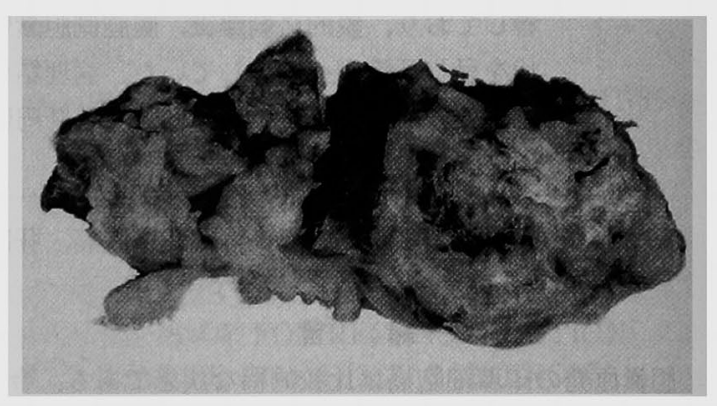

図 3 胆要切除標本 : 切除した腹腔側胆集壁は, 結石が 嵌屯していた部分を除き, 粘膜面全てに腫瘍を認めた。

が嵌屯していた部分以外の全ての粘膜面に腫瘍を認め た(図 3 ).

病理組織学的所見：核は細胞質の一側に圧平され半 月状を呈し, 細胞質内にはPAS 染色陽性の粘液が産 生され充满していた. 病理診断は signet ring cell carcinoma, INF- $\beta$, ly2, v2であった (図4).

術後経過：術後 3 日目に肺炎を発症。さらに同日よ り右片麻痺と言語障害を主とする脳梗塞も併発, 意識 レベルも急激に低下した，また，留置していたドレー ンの排液が再び血性を呈し徐々に増強, 貧血も認める ようになった. 後出血の可能性も考え再開腹を考慮し たが, 家人はこれ以上の積極的な治療を望まず, 輸血 と抗生物質の投与のみ開始した。一旦は改善傾向を認 めたものの, 今度は血性胸水が貯留するようになり， 胸腔ドレーンを留置し持続的に除去した。その後尿路 感染症から敗血症を呈し多臓器不全に陥り, 術後39日 目に死亡された。 


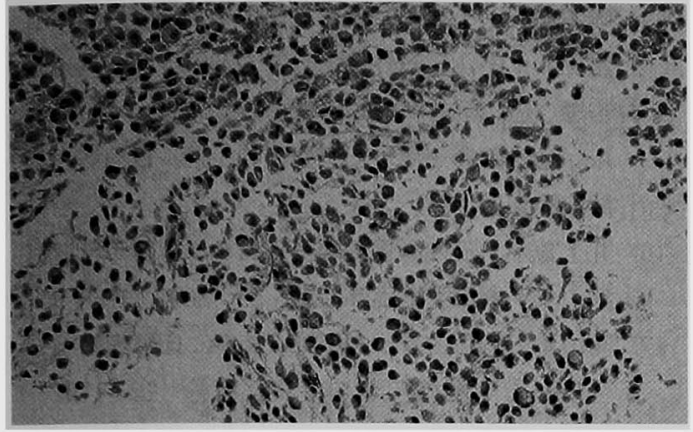

図 4 胆芜の病理組織学的所見 $(\mathrm{HE} \times 200)$ : 核は一方に 偏在し, 細胞質内には PAS 染色陽性の粘液が充泟して いる.

\section{考察}

胆䧶癌は, 組織学的にはそのほとんどが腺癌であり, 未分化癌や扁平上皮癌も時にみられるとされる の中で印環細胞癌は基本的には低分化型腺癌とされ, その $90 \%$ は胃に発生し, 胆賈は $2 \%$ 前後と報告されて いる2. また, 胆襄癌切除例における印環細胞癌の占め る割合は $0.3 \%$ 前後できわめて稀であり ${ }^{3)}$, 報告例も私 達が医学中央雑誌刊行会にて検索しえた限りに於いて はわずかに18例を確認するにすぎなかった2) 199. 一般 にその進行は早く，発見時には既に進行癌である場合 が多かった，本例も入院時に，既に胆裹床辺りに腫場 の浸潤によるまだら状の低吸収域を認める状態であっ たが, 術前の腫瑒マーカーが正常值であったため, 胆 囊炎の症状と合わせその部は膿瘍と思われていた。し かしながら胆桽癌における腫瘍マーカーの陽性率は高 くなく, さらに癌の分化度が高い方がマーカー值は高 くなる傾向があるといわれるため4), 結果的に今回は 診断の一助と成り得るものではなかった. 本例は内科 にて胆石胆露炎としてまず保存的に治療を開始し, 精 查を進める間に急激な上腹部痛の再発により穿孔が疑 われ緊急手術となってしまった. そのため消化管の精 查が十分に行われず，さらに剖検も同意が得られなか つた為施行出来ていない. しかし開腹時における肉眼 および触診所見で周囲他㵴器に転移をきたすような明 らかな腫瘍病変を認めなかったことから, 胆嚢原発で あると診断した.

また肝円索内血腫に関しては, 過去に胆䡖癌と合併 例の報告はなく，また文献的に検索しえたわずか 1 例 の肝円索内血腫の報告にても詳細までは確認できなか った為,その成因に関しては全く不明である ${ }^{20)}$. 本例で
は血腫と胆桽癌との間には明らかな交通は認められ ず, 癌腫からの出血が皮膜下を通って少し離れた肝円 索内に貯留したとは考えづらかった。術前もPT, APTT の凝固系は正常範囲内で出血傾向も認めては いなかったが, 長年に渡って高血圧と糖尿病を治療せ ず放置していたことや術後血管に起因するトラブルが 続いたこと等を考えると, 血腫内に明らかな出血点は 証明されなかったものの, 併存する他疾患により肝を はじめとする全身の血管壁が脆弱化を生じていた所 に, 腫瘍の浸潤等で何らかの機序が働き, 肝円索内の 血管の内圧の上昇あるいは亀裂が起こり, 結果血管が 破綻をきたして出血し, 比較的圧が逃げやすい場所て あったこともあって，巨大な血腫を形成したのではな いかと推測された。

今回の症例は術後の合併症により不幸な転帰を辿っ てしまったが, 腹部激痛の原因が血腫によるものと当 初から確信出来れば，現病歷も考慮し，まず穿針ドレ ナージや血管造影および塞栓術等の他治療法を選択す

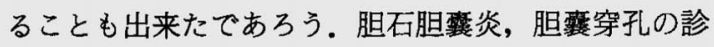
断で一期的に開腹切除術を行ったことは, 結果的には 適切だったとは思えず, 改めて急性腹症の的確な治療 方針の決定の難しさを反省させられた.

\section{結 語}

今回私達は肝円索内に巨大な血腫を形成した比較的 稀な胆囊の印環細胞癌を経験した。このような症例は 現在までに報告がなく, 若干の文献的考察を加え報告 した.

\section{文献}

1）税所宏光：胆道腫㿠. 丹羽寞文, 中沢三郎, 辻 孝 夫, 杉町圭造編, ベッドサイド消化器病学, 南江 堂, 東京, 1996, p802-807

2) 宇野健司, 鹿志村純也，井上 淳他：表面隆起型 を呈した胆萑印環細胞癌の 1 例. Prog Dig Endosc 消内視鏡の進歩 $62: 114,2002$

3）赤井祐一, 春日広一, 荒川泰行他：正常大胆襄に みられた印環細胞癌の 1 例.日大医誌 $61 ： 242-$ 244,2002

4）清原 薫, 小杉光世, 家接健一他: 胆壤印環細胞 癌の 1 例. 胆と脺 $19: 325-329,1998$

5）田近洋介, 苗加友貴子, 吉田美香他：印環細胞型 癌領域を伴った胆囊癌症例。日臨細胞会誌 41 ： 199, 2001

6）杉浦 博, 高橋 弘, 下沢英二他：胆露印環細胞 癌の 1 例. 日臨外会誌 $62: 2771-2775,2001$ 
7）飯村泰昭, 前山義博, 阿部島浽樹地：皮庙転移を 契機に発見された胆印印棵細胞癌の1例. 日蹦外 会誌 $61: 3122,2000$

8）山内希美, 尾関 豊, 角 泰廣 他: 膵管胆道合流 異常をともなった胆衰印環細胞癌の 1 例.日消病 会誌 $97: 204-208,2000$

9）寺澤晃同、遠藤聡子、小林津月 他：子宮と卵巣へ 転移をきたした胆焦印環細胞癌の1例。日産婦中 国四国会誌 $47: 228,1999$

10）瀬戸啓太郎，長谷川泰介，瀨島照弘地：胆亳原発 印環細胞癌の 1 例。日消病会誌 $95: 288,1998$

11）四方 敦, 森紀久朗, 綿引洋一他: Cisplatin 動注 療法が著奻した切除不能進行胆垬癌の 1 例. 癌と 化療 $24 ： 1820-1824 ， 1997$

12）土田明彦, 粕谷和彦, 安田祥浩 他: 印環細胞癌像 を伴った胆榛腺扁平上皮癌の 1 例。胆道 $10: 162$ $-168,1996$

13）水谷佐世子, 大沼俊和, 武山直治他：石灰化を伴 う胆衰癌の 1 例。胆と脺 $17: 291-296,1996$
14）味木徹夫, 小野山裕彦，富田政雄他：胆毫印環細 胞癌の 1例，日消外会誌 $27: 2007-2009 ， 1994$

15）佐藤 徹，新井一成，荒瀬 勉他：いわゆる Kru-

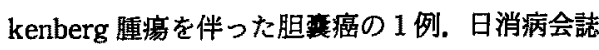
$90: 2648,1993$

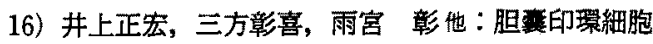
癌の 1 手街例。日臨外会誌 $50: 2091,1989$

17）浦山雅広，石山秀一，豊野充他：印環細胞癌を 合併した掏器樣胆㟟の 1 峢. 消外 $12: 1767-$ 1770, 1989

18）本間 卓，高橋牧郎，堀内隆之他：胆赛原発印環 細胞癌の 1 例. 日消病会誌 $84: 1515,1987$

19）大坪哲也，福山邦明，吉原幸治郎他：全身骨転移

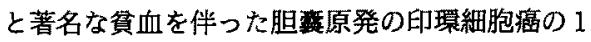
例. 日内会誌 $74: 123,1985$

20）二宮英彦，岡村博文，中田 良他：肝円索に生し 診断が困難であった血腫の 1 例. 日消病会誌 $89: 991,1995$

\title{
A CASE REPORT OF SIGNET RING CELL CARCINOMA OF THE GALL-BLADDER WITH A HUGE HEMATOMA IN THE LIGAMENTUM TERES HEPATIS
}

\author{
Akinori MURAOKA, Takao HORIBA, Tsukasa NAKAMURA, \\ Masuo NONOYAMA and Toshiya NAGAI \\ Department of Surgery, Seirei Hospital
}

Signet ring cell carcinoma of the gallbladder, especially the disease associated with a hematoma in the ligameritum teres hepatis, is rare. This paper deals with a case of signet ring cell carcinoma of the gallbladder in a patient who developed huge hematoma formation in the ligamentum teres hepatis during examination for cholelithiasis and cholecystitis which demanded emergency operation.

A 72 -year-old woman brought into the emergency clinic in our hospital by ambulance for acute abdomen was admitted to the department of internal medicine with a diagnosis of cholelithiasis and cholecystitis. Conservative treatment resulted in temporary remission, but she had an attack of severe upper abdominal pain and the levels of WBC and CRP were elevated again. Computed tomography (CT) showed a large low density area at the surface of the left lobe of the liver and moderate amount of ascites. Perforation of the gallbladder was suggested, and so emergency operation was performed on the same day. At laparotomy a hematoma was present in the ligamentum teres hepatis and the gallbladder was firmly applied to the surrounding organs. After dissecting these adhesions, cholecystectomy and drainage of the hematoma were performed. Entire mucosa surface of the gallbladder presented tumorous appearance and invaded the liver. Histopathological diagnosis was signet ring cell carcinoma of the gallbladder. 